\title{
The effect of Polygonum minus extract on cognitive and psychosocial parameters according to mood status among middle-aged women: a randomized, double-blind, placebo-controlled study [Retraction]
}

Shahar S, Aziz AF, Ismail SNA, et al. The effect of Polygonum minus extract on cognitive and psychosocial parameters according to mood status among middle-aged women: a randomized, double-blind, placebo-controlled study. Clin Interv Aging. 2015;10:1505-1520.

This article has been retracted at the request of the Editor-inChief of Clinical Interventions in Aging. It was brought to the attention of the Editorial team by the authors that there were a number of reporting errors in the Methods, Results and Figures 3-5. Due to the extent of the inaccuracies, the scientific validity of the data, and hence the conclusions, are questionable.
Clinical Interventions in Aging

\section{Publish your work in this journal}

Clinical Interventions in Aging is an international, peer-reviewed journal focusing on evidence-based reports on the value or lack thereof of treatments intended to prevent or delay the onset of maladaptive correlates of aging in human beings. This journal is indexed on PubMed Central, MedLine,

\section{Dovepress}

CAS, Scopus and the Elsevier Bibliographic databases. The manuscript management system is completely online and includes a very quick and fair peer-review system, which is all easy to use. Visit http://www.dovepress. com/testimonials.php to read real quotes from published authors. 